SHORT COMMUNICATIONS

Proc. Estonian Acad. Sci. Biol. Ecol., 2001, 50, 1, 33-36

\title{
SENSITIVITY OF PLATELETS TO PROSTAGLANDINS IN PATIENTS WITH CORONARY ARTERY DISEASE
}

\author{
Vilja MARDLA ${ }^{\mathrm{a}}$, Gennadi KOBZAR ${ }^{\mathrm{a}}$, Indrek RÄTSEP ${ }^{\mathrm{b}}$, Madis LÕHMUS ${ }^{\mathrm{a}}$, \\ Ivar JÄRVING ${ }^{\mathrm{a}}$, and Nigulas SAMEL ${ }^{\mathrm{a}}$ \\ a Institute of Chemistry, Tallinn Technical University, Akadeemia tee 15, 12618 Tallinn, Estonia; \\ vilja@ chemnet.ee \\ b Mustamäe Hospital, Sütiste tee 19, 13419 Tallinn, Estonia
}

Received 31 August 2000, in revised form 3 November 2000

\begin{abstract}
The platelet sensitivity to the antiaggregatory prostaglandins $\left(\mathrm{PGE}_{1}, 13,14\right.$-dihydro- $\mathrm{PGE}_{1}$, and 5,6-dihydro- $\mathrm{PGE}_{3}$ ) was studied in patients with coronary artery disease. Platelets of healthy subjects were used as control. The sensitivity was tested in vitro by inhibiting the adenosine diphosphate-induced platelet aggregation with these prostaglandins of various concentrations. In the patients the antiaggregatory potency of the prostaglandins was significantly lower than in healthy subjects.
\end{abstract}

Key words: platelets, prostaglandins, coronary artery disease.

Abbreviations: $\mathrm{PG}=$ prostaglandin $; \mathrm{PGE}_{1}=$ prostaglandin $\mathrm{E}_{1} ; 13,14$-dihydro- $\mathrm{PGE}_{1}=$ prostaglandin 13,14-dihydro- $\mathrm{E}_{1} ; 5,6$-dihydro- $\mathrm{PGE}_{3}=$ prostaglandin 5,6 -dihydro- $\mathrm{E}_{3} ; \mathrm{PGI}_{2}=$ prostaglandin $\mathrm{I}_{2}$, prostacyclin; $\mathrm{ADP}=$ adenosine diphosphate $\mathrm{CAD}=$ coronary artery disease; $\mathrm{PRP}=$ platelet-rich plasma.

\section{INTRODUCTION}

Prostaglandin $\mathrm{E}_{1}\left(\mathrm{PGE}_{1}\right)$ and its natural analogues prostaglandin 13,14dihydro- $\mathrm{E}_{1}\left(13,14\right.$-dihydro- $\left.\mathrm{PGE}_{1}\right)$ and prostaglandin 5,6-dihydro- $\mathrm{E}_{3}(5,6-$ dihydro- $\left.\mathrm{PGE}_{3}\right)$ interact with the same platelet receptor as prostacyclin $\left(\mathrm{PGI}_{2}\right)$. These prostaglandins (PGs) are synthesized in the organism in very low quantities, but are very potent inhibitors of platelet aggregation (Kobzar et al., 1993). Sinzinger et al. (1998) showed that $\mathrm{PGE}_{1}$ and 13,14-dihydro-PGE ${ }_{1}$ inhibit platelet adhesion to the vessel wall as well as platelet thrombus formation and 
induce thromboresistance in experimental animals and in man. There are no data in the literature on the effect of 13,14-dihydro-PGE ${ }_{1}$ and 5,6-dihydro- $\mathrm{PGE}_{3}$ on platelets of patients suffering from coronary artery disease (CAD). Therefore in this work we compared the antiaggregatory potency of these PGs in patients suffering from advanced CAD with that of age and sex matched healthy subjects.

\section{MATERIALS AND METHODS}

The studied patients suffered from CAD and underwent coronary artery bypass grafting. Preliminary coronary angiography showed $\geq 75 \%$ lumen narrowing in at least one coronary artery. All patients gave informed consent and the local ethics committee approved the study. Donors of the local blood bank served as control. Blood samples were taken from the radial artery through an indwelling catheter before cardiopulmonary bypass in the patients and from the antecubital vein in the healthy subjects.

Blood was collected into 10-mL plastic centrifuge tubes containing $1 \mathrm{~mL}$ of $3.8 \%$ trisodium citrate. Platelet-rich plasma (PRP) and platelet-poor plasma were prepared by centrifugation of the citrated blood at $160 \times g$ or $4000 \times g$ for $10 \mathrm{~min}$ at room temperature, respectively.

Aggregation was measured photometrically in a Chrono-Log aggregometer according to the method of Born (1962) by detecting the transmission of the light through PRP. An aggregometer cuvette containing $0.5 \mathrm{~mL}$ of an aliquot of PRP was maintained at $37^{\circ} \mathrm{C}$ and stirred with a Teflon coated stirring bar at $1200 \mathrm{rpm}$. Inhibition of platelet aggregation was determined by incubation of PGs with PRP.

The $\mathrm{IC}_{50}$ was calculated from dose-effect curves as a concentration necessary to reduce the ADP-induced aggregation by $50 \%$ of its control amplitude. Data were expressed as arithmetic mean \pm standard error (SEM) of separate experiments with PRP of $n$ subjects. Statistical significance of healthy donors versus CAD patients was determined using the Student's $t$-test for an unpaired experiment.

PGs were dissolved in ethanol, kept at $-20{ }^{\circ} \mathrm{C}$, and diluted with saline before the experiment. $\mathrm{PGE}_{1}$ was obtained from Kemasol Ltd. (Tallinn, Estonia). 5,6-Dihydro- $\mathrm{PGE}_{3}$ was separated by repeated HPLC-purification from the mixture of natural E-PGs extracted from ram seminal vesicles (Lõhmus et al., 1990). 13,14-Dihydro- $\mathrm{PGE}_{1}$ was synthesized from $\mathrm{PGE}_{1}$ by the reduction of the 13,14 double bound with $\mathrm{H}_{2}$ on the $\mathrm{Pd}(\mathrm{C})$ catalyst. The purity of the PGs used for the platelet antiaggregatory study was more than $99.9 \%$ by HPLC.

\section{RESULTS}

The chemical structure of the PGs studied is shown in Fig. 1. All three compounds were about two times less effective in CAD patients than in control (Table 1). These data are in accordance with the earlier studies, which showed 

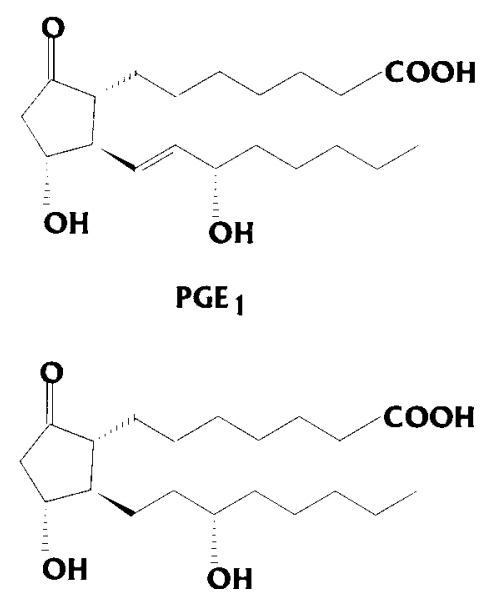

13,14-dihydro-PGE

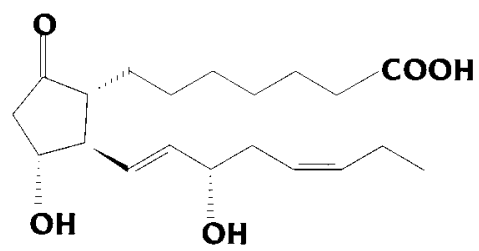

5,6-dihydro-PGE 3

Fig. 1. Chemical structure of the prostaglandins under study.

Table 1. Inhibition of ADP-induced platelet aggregation in healthy subjects and patients with CAD

\begin{tabular}{l|c|c|c|c|c}
\hline \multirow{2}{*}{ Compound } & \multicolumn{2}{c|}{ Healthy subjects } & \multicolumn{2}{c|}{ CAD patients } & \multirow{2}{*}{$P$-value } \\
\cline { 2 - 5 } & $\mathrm{IC}_{50}, \mathrm{nM}$ & $n$ & $\mathrm{IC}_{50}, \mathrm{nM}$ & $n$ & \\
\hline PGE $_{1}$ & $56 \pm 5$ & 11 & $120 \pm 20$ & 11 & $<0.01$ \\
13,14-Dihydro-PGE & $35 \pm 6$ & 11 & $86 \pm 12$ & 11 & $<0.01$ \\
5,6-Dihydro-PGE & $58 \pm 6$ & 10 & $110 \pm 9$ & 10 & $<0.01$
\end{tabular}

Data are expressed as arithmetic mean \pm SEM of separate experiments with PRP of $n$ subjects. $\mathrm{IC}_{50}$ is the concentration causing 50\% inhibition of ADP-induced platelet aggregation. The statistical significance of healthy donors versus CAD patients was determined with unpaired Student's $t$-test.

a lower sensitivity of platelets of CAD patients to $\mathrm{PGI}_{2}$ (Mehta et al., 1980) and to $\mathrm{PGE}_{1}$ (Sinzinger et al., 1981). This effect may be explained by the fact that $\mathrm{PGI}_{2}$ synthesis is increased in blood vessels of CAD patients (Fisch et al., 1997) and long-term exposure of platelets to $\mathrm{PGI}_{2}$ may result in desensitization of $\mathrm{PGI}_{2}$ 
receptors. The lower sensitivity of platelets to 13,14-dihydro-PGE ${ }_{1}$ and 5,6dihydro-PGE 3 , as well as to $\mathrm{PGE}_{1}$ and $\mathrm{PGI}_{2}$, may be used as an indicator of CAD.

\title{
ACKNOWLEDGEMENT
}

The research was supported by the Estonian Science Foundation (grant No. 3736).

\section{REFERENCES}

Born, G. V. R. 1962. Aggregation of blood platelets by adenosine diphosphate and its reversal. Nature, 194, 927-929.

Fisch, A., Tobusch, K., Veit, K., Meyer, J. \& Darius, H. 1997. Prostacyclin receptor desensitization is a reversible phenomenon in human platelets. Circulation, 96, 756-760.

Kobzar, G., Mardla, V., Järving, I., Lõhmus, M., Vahemets, A., Samel, N. \& Lille, Ü. 1993. Comparison of the inhibitory effect of E-prostaglandins in human and rabbit platelet-rich plasma and washed platelets. Comp. Biochem. Physiol., 106C, 489-494.

Lõhmus, M., Vahemets, A., Järving, I., Samel, N., Lille, Ü. \& Pehk, T. 1990. Preparative separation of natural prostaglandin E. Prep. Chromat., 1, 279-300.

Mehta, J., Mehta, P. \& Conti, C. R. 1980. Platelet function studies in coronary heart disease. IX. Increased platelet prostaglandin generation and abnormal platelet sensitivity to prostacyclin and endoperoxide analog in angina pectoris. Am. J. Cardiol., 46, 943-947.

Sinzinger, H., Schernthaner, G. \& Kaliman, J. 1981. Sensitivity of platelets to prostaglandins in coronary heart disease and angina pectoris. Prostaglandins, 22, 773-781.

Sinzinger, H., Neumann, I., O’Grady, J., Rogatti, W. \& Peskar, B. A. 1998. Effects of prostaglandin $\mathrm{E}_{1}$ metabolites on the induction of arterial thromboresistance. Prostaglandins Other Lipid Mediators, 55, 265-275.

\section{KORONAARTÕVEGA PATSIENTIDE TROMBOTSÜÜTIDE TUNDLIKKUS PROSTAGLANDIINIDE SUHTES}

\author{
Vilja MARDLA, Gennadi KOBZAR, Indrek RÄTSEP, Madis LÕHMUS, \\ Ivar JÄRVING ja Nigulas SAMEL
}

Eksperimentaalselt on uuritud koronaartõvega patsientide trombotsüütide tundlikkust antiagregatiivsete prostaglandiinide $\left(\mathrm{PGE}_{1}, 13,14\right.$-dihüdro- $\mathrm{PGE}_{1}$ ja 5,6-dihüdro- $\mathrm{PGE}_{3}$ ) suhtes. Tervete doonorite trombotsüüte on kasutatud kontrolliks. Trombotsüütide tundlikkust on testitud in vitro inhibeerides prostaglandiinidega adenosiindifosfaadi toimel indutseeritud trombotsüütide agregatsiooni. Koronaarhaigusega patsientidel oli nende prostaglandiinide antiagregatiivne aktiivsus tunduvalt madalam võrreldes tervete kontrollgrupiga. 